\title{
REALIZATION OF THE LEGISLATIVE COMPETENCE OF LOCAL MUNICIPALITY AUTHORITIES
}

\section{Roman Liashuk}

\section{INTRODUCTION}

Local self-government in Ukraine is a state-guaranteed right and a real capacity of the territorial community of residents of a village or voluntary association of residents of several villages, settlements, cities independently or under the responsibility of bodies and officials of local self-government to resolve issues of local importance within the Constitution and laws of Ukraine. Regulatory decisions can be made both directly by the territorial community through a local referendum and through representative bodies of local self-government (village, settlement, city, district and regional councils).

Recent decades have become historic for local government in Ukraine. It has received public and state recognition, is enshrined in the Constitution of Ukraine, has developed a regulatory framework and has extensive experience. There was a rather intense and stable development of the science of municipal law, formed a domestic municipal law school. Established non-governmental organizations promoting local self-government: Association of Ukrainian Cities ${ }^{1}$, Interregional Union of Local Self-Government Bodies, Foundation for Promotion of Local Self-Government in Ukraine ${ }^{2}$ and others.

\section{General characteristics of municipal rulemaking}

For the study of municipal rulemaking, the determination of the nature of local self-government and its relation with state power are of paramount importance. The question of what it is must be resolved local government, what they are its legal features and properties that determine not only its functional purpose, but also the forms of its implementation.

\footnotetext{
${ }^{1}$ Asotsiatsiya mist Ukrayiny [Association of Ukrainian Cities]. URL:https://www.auc.org.ua/proposal

${ }^{2}$ Pro Derzhavnyy fond spryyannya mistsevomu samovryaduvannyu $v$ Ukrayini [About the State Fund for Promotion of Local Self-Government in Ukraine]: Presidential Decree of June 24, 2010, № 723/2010. - URL:https://zakon.rada.gov.ua/laws/show/723/2010
} 
This approach reflects not only theoretical interest in local selfgovernment, but also has applied value, since the establishment of legal features and properties of local self-government contributes to a proper understanding of the purpose and content of municipal rulemaking. At the same time, it should be noted that the concept of «municipal rulemaking», along with another similarly meaningful term «municipal lawmaking» is only being introduced into scientific circulation, and the concept of «local government» has long been referred to in the terminology of legal science.

The legislation of Ukraine on local self-government empowers the subject of local self-government with public authority, which allows it to resolve issues of local importance, either directly or through bodies created by it. Individuals do not have such authority as members of the territorial community, they have the right to participate in local selfgovernment in statutory forms.

Local self-government is a separate form of exercise of public authority, Art. 5 of the Constitution of Ukraine" :People are the bearer of sovereignty and the sole source of state power in Ukraine. The people exercise state power directly and through state authorities.» As a subject of local self-government, the territorial community has the right to resolve issues of local importance in any legal form.

The specific subject of local self-government is defined in item 1 of Art. 3 of the European Charter of Local Self-Government of 15 October 1985 (hereinafter: the Charter of Local Self-Government) ${ }^{4}$ because of the concept of «a large part of state affairs», in Art. 140 of the Constitution of Ukraine and Art. 2 of the Law on Local Self-Government through the concept of «local issues». Or abstract concepts are partly specified in Art. 143 of the Constitution of Ukraine and several articles of the Law on Local Self-Government.

Naturally, the constitution of a modern democratic state cannot contain an exhaustive list of issues pertaining to local self-government, and therefore, the specific laws (in Ukraine - in the Law on Local SelfGovernment) are specified in many signatories of the Charter of local self-government. In order to specify the subject of local self-government

\footnotetext{
${ }^{3}$ Konstytutsiya Ukrayiny [Constitution of Ukraine]: Adopted at the fifth session of the Verkhovna Rada of Ukraine on June 28, 1996 - URL: https://zakon.rada.gov.ua/laws/show/254\%D0\%BA/96-\%D0\%B2\%D1\%80

${ }^{4}$ Yevropeys'ka khartiya mistsevoho samovryaduvannya [European Charter of Local SelfGovernment]: 15 October 1985. - URL:https://zakon.rada.gov.ua/laws/show/994_036
} 
in European countries, two criteria are used: formal and legal - referring to local issues by the legislation on local self-government, and material ensuring the livelihood of territorial communities ${ }^{5}$.

Local self-government is not at all opposed to state power. The explanation for this is to be found in the very nature of these two social phenomena, in that state power and local self-government are only different forms of self-organization of society.

Legal features and properties of local self-government in Ukraine:

1) local self-government is structured in the system of public authority in the form of public-self-government in the process of state awareness of the presence of other, non-state interests - interests of local character, which are not identical to the state, but not contrary to them;

2) local self-government is characterized by a high level of democracy, and its subject is a territorial community consisting of residents who are permanently resident within a certain territory;

3 ) the main purpose of structuring local self-government in the public authority system is to address local issues most effectively ${ }^{6}$.

Many social relations, in view of their content, local conditions and peculiarities, require the publication of normative-legal acts of local selfgovernment in order to specify the norms of legislation. Municipal rulemaking is not carried out only in cases where the rules of the law directly regulate public relations in the sphere Local Government. With the exception of these cases, legal regulation public relations on the basis of and for the implementation of the law is ensured by issuing regulations of local self-government and local action.

In the science of municipal law, the opinion of the subordinate nature of the rulemaking activity of local self-government bodies is quite common. The powers of local self-government bodies in the field of adoption of normative legal acts are based on the delegation by the state to the municipal level of authority of law-making powers. Issuing legal

5 Barksiy V.R. (2006) Normotvorchist' predstavnyts'kykh orhaniv mistsevoho samovryaduvannya $v$ Ukrayini [Rulemaking of representative bodies of local self-government in Ukraine]. - Odessa. - 221 p. P. 13.

6 Barksiy V.R. (2006) Normotvorchist' predstavnyts'kykh orhaniv mistsevoho samovryaduvannya $v$ Ukrayini [Rulemaking of representative bodies of local self-government in Ukraine]. - Odessa. P. 18. 
acts by local governments on their competence is a law-making, previously authorized by the state ${ }^{7}$.

Local authorities, which are excluded from the system of state bodies, cannot assign to themselves the function of law-making, because it is the most important state function. Only the state or its separate bodies can authorize the creation by the local self-government bodies of legal norms that give rise to legal rights and obligations.

Authorization of rulemaking activity of local self-government bodies is carried out in the following ways:

local self-government bodies, on their own initiative, develop norms that acquire the legal character of a prior state sanction;

state bodies approve the normative acts developed by selfgovernment bodies;

the state creates general (typical) norms in the form of recommendations, and local governments detail them in relation to specific conditions and submit them for approval (registration) to the relevant public authority ${ }^{8}$.

It should be noted that the above characteristic of the properties of municipal rulemaking is only partially undeniable. On the one hand, the rulemaking activity of local self-government bodies is a way of fulfilling their self-governing powers and delegated powers of executive bodies. On the other hand, local self-government seems to be an expression of will that is carried out in the light of Art. 140 Constitution of Ukraine by the territorial community directly or through bodies local selfgovernment and is not based, therefore, on delegation to him by the state of law-making powers.

The general legal features of municipal rulemaking as a form of lawmaking include its social purpose, which is to set certain standards, requirements for the behavior of participants in legal relationships.

Specific legal features of municipal rulemaking reflect the functional purpose of local self-government, the form of its implementation.

Municipal norm-making expresses the will of a local government entity - a territorial community. Municipal rulemaking is carried out by the territorial community directly or through local governments. The

Maslovskaya T.S. (1998) Normotvorchestvo organov mestnogo samoupravleniya Rossiyskoy Federatsii [Rulemaking of local authorities of the Russian Federation]. - Omsk. 23 s. (in Russian).

${ }^{8}$ Shugrina E.S. (2000) Munitsipal'noye pravo [Municipal Law]. Moscow: Case. - 496 s. (in Russian). 
subject of legal regulation of normative legal acts that are created within the framework of municipal rulemaking, are mainly issues related to the subject of local government - that is, issues of local importance.

Municipal rulemaking authority is directly related to the municipalterritorial system, because the public-self-government is exercised in a certain territory. Local self-government regulations are the legal means of exercising power in a localized territory, making their scope limited by the respective territory of the administrative and territorial unit and the number of entities located in that territory.

Municipal rulemaking is carried out in the form of a rulemaking process. The rulemaking process is a system of interdependent, specially ordered actions and operations subject to a specific purpose, which, through appropriate techniques and means, leads to a specific result, the method of communication of which is an appropriate procedural and procedural form? ${ }^{9}$. It should be borne in mind that the concept of «municipal rulemaking» covers: direct rulemaking of the territorial community (local referendum) and rulemaking of representative bodies of local self-government. Each of the varieties of municipal rulemaking is different in legal regulation and procedural form.

\section{Competence of local self-government bodies in the field of rulemaking}

Local self-government is a complex socio-political institute of modern society. The municipal legislation of Ukraine provides for a complex structural and organizational mechanism for the implementation of local self-government, called the "system of local self-government" ${ }^{\text {"10 }}$.

У структурно-організаційному плані система являє собою сукупність органів місцевого самоврядування, органів самоорганізації населення й організаційних форм, за допомогою яких відповідна територіальна громада чи іiі складова частина здійснюють задачі і функції місцевого самоврядування, вирішують завдання місцевого значення.

According to the Law on Local Self-Government, this system includes: territorial community; village, settlement, city council; village,

\footnotetext{
9 Onischenko N. (2002) Yurydychnyy protses yak forma pravovoyi diyal'nosti [Legal process as a form of legal activity] Law of Ukraine. - № 7. - P. 7-13. (in Ukrainian).

${ }^{10}$ Bilenchuk P.D, Kravchenko V.V., Podmogilny M.V. (2000) Mistseve samovryaduvannya v Ukrayini (munitsipal'ne pravo) [Local Self-Government in Ukraine (Municipal Law)] Kyiv: Attica. - 304 p. Pp. 25-26. (in Ukrainian).
} 
town, mayor; executive bodies of the village, settlement, city council; district and regional councils representing the general interests of the territorial communities of villages, towns and cities; bodies of selforganization of the population (Art.5) ${ }^{11}$. Each element of this system plays a special role in the implementation of local self-government.

The leading role in this system belongs to the territorial community. However, as stated earlier, the provisions on the right of territorial communities to resolve local issues cannot be absolutized. For a number of objective reasons, territorial communities are virtually unable to directly exercise their right to local self-government, leading modern scholars to believe that it is not the local community but the local selfgovernment that should be considered a core element of the local selfgovernment system. According to leading domestic legal scholars, state and local affairs are more effectively able to carry out on-site relevant bodies, unlike the community, on a permanent basis, qualified and should be held accountable for their activities not inherent in the territorial community ${ }^{12}$.

The system of representative bodies of local self-government consists of two levels (subsystems): 1) village, town, city councils; 2) district, regional councils.

The presence of these two levels of representative bodies of local self-government does not mean subordination of one to the other. Their representative nature differs: rural, settlement, city councils represent relevant territorial communities; district and regional councils - general interests of territorial communities of villages, towns and cities.

Legal regulation of the activity of the vast majority of representative bodies of local self-government is carried out by the norms of the Constitution of Ukraine, legislative acts and their regulations. An exception to this rule is the additional regulation of certain aspects of the activity of local councils by the norms of the statutes of territorial communities, if adopted. As a result, the legal rules governing the activity of local councils have different legal force, which depends on the place in the hierarchy of legal acts that the act in which they are contained.

${ }^{11}$ Pro mistseve samovryaduvannya v Ukrayini [On Local Government in Ukraine]: Law of Ukraine of May 21, 1997, № 280/97-BP. - URL: https://zakon.rada.gov.ua/laws/show/280/97-вp

${ }^{12}$ Pogorilko V.F., Fritsky O.F. (2001) Munitsypal'ne pravo Ukrayiny [Municipal Law of Ukraine] Kyiv: YurinkomInter. - 352 p. Pp. 151-152. (in Ukrainian). 
The subjects of municipal normative legal relations are significantly different from each other by the level of legal knowledge. Against this background, they have different interpretations of the purpose of regulations, which ultimately leads to the fact that different local councils regulate the same issues, both by legal and individual acts. But such a situation is unacceptable because it violates the unity of the legal space of Ukraine. The attribution of a legal act of a local council regulating a particular issue to one of two types - regulatory or individual - determines the features of its preparation, adoption, promulgation, entry into force.

Local self-government normative act is the legal result of rulemaking activity, which is motivated by the objective need for legal registration of relevant social relations. It is adopted for the purpose of regulating social relations that are within the scope of local government.

Taking into account the social purpose of local government regulations, their adoption is carried out in a strictly defined procedural and procedural form.

A legal act enters into force only upon its official publication. Its implementation is provided by various means, including means of coercion, which is justified by «concern for the public good». Failure to enforce or improperly enforce a local government normative act entails legal liability.

Local self-government regulation is an official document adopted directly by the territorial community or representative body of local selfgovernment within the scope of the subject of local self-government, in a certain procedural and procedural form, aimed at establishing, modifying, supplementing or abolishing legal rules designed for repeated use of prescriptions. Legal acts of local self-government that do not meet the above characteristics are individual.

The procedure for adopting acts of local self-government bodies and officials is defined in Art. 59 of the Law of Ukraine "On Local SelfGovernment in Ukraine“"13.

The Council, within the limits of its powers, adopts regulations and other acts in the form of decisions. The decision of the council is taken at its plenary session after discussion by the majority of the members of the general council. In determining the results of the vote, the chairman shall

${ }^{13}$ Pro mistseve samovryaduvannya v Ukrayini [On Local Government in Ukraine]: Law of Ukraine of May 21, 1997, № 280/97-BP. - URL: https://zakon.rada.gov.ua/laws/show/280/97-вp 
be included in the general composition of the council if he or she participates in the plenary meeting of the council and his vote is taken into account. The decision of the Board is made by open (including roll call) or by secret ballot. The decision of the council within five days from the moment of its adoption can be stopped by its chairman and submitted for reconsideration of the respective council with justification of the comments. The council is bound to reconsider the decision within two weeks. If the council rejects the chairman's remarks and affirms the previous decision by two-thirds of the council members, it shall enter into force. Decisions of the regulatory board shall enter into force on the day of their official promulgation, unless the board has a later date for the implementation of these decisions. In particular, an example of a decision of the regulatory character of representative bodies of local selfgovernment is the decision of the city council «On approval of the Rules for the organization of collection, transportation, recycling and disposal of solid household waste in the city» of June 12, 2008 № 157 or «On approval of the procedure for the competition for the right to lease of communal property «dated 7.06.2007 № 772 .

The executive committee of the village, settlement, city, district in the city council within its powers makes decisions. Decisions of the Executive Committee are taken at its meeting by a majority of votes from the general composition of the Executive Committee and are signed by the village, town, city, district head of the city council. In case of disagreement of the mayor, the mayor (the mayor of the district in the city council) with the decision of the executive committee of the council, he may suspend the decision by his own order and submit the matter to the relevant council.

The village, settlement, city mayor, the chairman of the district in the city, the district, regional council within its powers issues orders.

Decisions of the executive committee of the council on matters within the competence of the executive bodies of the council may be reversed by the relevant council.

Permanent commissions, on behalf of the council, the chairman, respectively the deputy chairman of the district in the city, the district council or the first deputy, the deputy chairman of the regional council, the secretary of the village, settlement, city council or on their own initiative, study the activities of the accountable and controlled councils and the executive committee of the village, city, district and city councils of bodies, as well as issues related to the management of the council, local state administrations, enterprises, institutions and organizations, 
their branches and offices regardless of ownership and their officials, submit on the results of verification of the recommendation for consideration of their heads, and in necessary cases - for consideration by the council or the executive committee of the village, settlement, city, district in the city council; exercise control over the implementation of the Board's decisions, executive committee of village, settlement, city, district in city council ${ }^{14}$. The organization of the work of the standing committee of the council is vested in the chairman of the commission. The chairman of the commission convenes and conducts the meeting of the commission, gives orders to the members of the commission, represents the commission in relations with other bodies, associations of citizens, enterprises, institutions, organizations, as well as citizens, organizes work on the implementation of the conclusions and recommendations of the commission.

A meeting of the standing committee shall be convened as necessary and shall be competent if it is attended by at least half of the total composition of the commission.

A standing committee for the study of issues, drafting decisions of the council can create preparatory commissions and working groups with the involvement of members of the public, scientists and specialists. Issues related to the management of several standing committees may, on the initiative of the commissions, as well as on the instructions of the council, its chairman, respectively the deputy chairman of the district in the city, the district council or the first deputy, the deputy chairman of the regional council, the secretary of the village, settlement, city council joint committees. The conclusions and recommendations adopted by the standing committees at their joint meetings shall be signed by the chairmen of the respective standing committees.

Standing committee committees prepare and adopt conclusions and recommendations. Temporary control commissions submit reports and proposals to the city council.

Deputies of city council on the basis of party affiliation can unite in deputy factions. Deputies may also include non-partisan city council deputies. The order of entering and leaving the faction is determined by the faction itself. A deputy may be a member of only one faction ${ }^{15}$.

\footnotetext{
${ }^{14}$ Rusnak B.A. (2011) Mistseve samovryaduvannya v Ukrayini: teoriya i praktyka [Local self-government in Ukraine: theory and practice]. - Odessa. P. 127. (in Ukrainian).

${ }^{15}$ Rusnak B.A. (2011) Mistseve samovryaduvannya v Ukrayini: teoriya i praktyka [Local self-government in Ukraine: theory and practice]. - Odessa. P. 238. (in Ukrainian).
} 
The parliamentary faction may be formed at any time within the term of office of the city council by the decision of the assembly of deputies who have expressed a desire to join it. The parliamentary faction defines the persons authorized to represent it in the council.

The decision to unite the deputies into a faction shall be notified to the deputies of the city council chairing the plenary session of the council on the basis of the minutes of the meeting of the faction and a written notice of the head of the faction, signed by members of the faction, indicating the name of the faction, personal composition, party affiliation.

At the next, after the registration of the deputy faction (group), the plenary session of the council, the chairman informs the deputies about the formation of the group (faction), its quantitative composition and the authorized representative.

Deputies' factions (groups) have the right: to submit proposals for consideration of issues at the plenary session of the council, as well as for inclusion of issues in the agenda of the session;

At the request of a faction (group), the council apparatus shall distribute the materials prepared by the faction (group) as a draft official document of the session of the council, if they are submitted for consideration by the session.

In order to take into account the historical, national-cultural, socioeconomic and other peculiarities of local self-government, a representative body of local self-government based on the Constitution of Ukraine and within the framework of this Law may adopt the statute of a territorial community of a village, settlement, city. Law of Ukraine "On Local Self-Government in Ukraine"16 contains a number of articles which explicitly state that a particular issue should be regulated not only by law but also by the statute of the territorial community. In particular, it concerns the procedure for forming and organizing the activity of councils (h. 4, Art. 10), holding general meetings of citizens at their place of residence (h. 3, Art. 8), the procedure for submitting a local initiative to the Council (h. 2, Art. 9). , organization of public hearings (Part 4 of Article 13), etc. Accordingly, the Model Statute of a territorial community may consist of the following main sections:

\footnotetext{
${ }^{16}$ Pro mistseve samovryaduvannya v Ukrayini [On Local Government in Ukraine]: Law of Ukraine of May 21, 1997, № 280/97-BP. - URL: https://zakon.rada.gov.ua/laws/show/280/97-вp
} 
In the first section «General Provisions» it is stated that the Statute of a territorial community in accordance with the Constitution of Ukraine, the Law of Ukraine «On Local Self-Government in Ukraine», other laws of Ukraine defines the legal principles, forms, procedure for exercising local self-government by the relevant territorial community, its bodies and officials due to historical, geographical, national-cultural, socioeconomic and other features of the given administrative-territorial unit (villages, settlements, cities). The same section gives a brief description of the relevant territorial community, in particular, whether it consists solely of citizens of Ukraine who reside within a given village, settlement, city, or residents of several settlements who have voluntarily united into one territorial community, including without preserving the independence of each of them (on the principle of municipal unitarism) or with maintaining such independence (on the principle of municipal federalism).

The second section of «Territory» gives a detailed description of the respective administrative and territorial unit. If it is a separate village, town, city, then its current and historical names are defined, year of establishment, division into districts, micro-districts and other microstructures, an exact description of the surrounding lands is under the jurisdiction of the respective territorial community and local selfgovernment bodies, the territory of the village is indicated, settlements, cities as an administrative unit.

In the third section «Material and financial base», are defined:

first, the communal property of a given territorial community: land and other natural resources; enterprises, institutions, organizations; housing and non-residential premises; the share of this community in communal property created or merged under contracts with other territorial communities; share in the capital of business structures; local budget revenues (indicating number, size, category, bank value, source of revenue, etc.).

secondly, the specificities of the legal regime of individual communal property are determined, including the list of those objects that are exclusively relevant to the collective needs of a given territorial community and are not subject to alienation without a decision, for example, by the territorial community itself.

The fourth section "Bodies and officials of local self-government" defines the features of the system of local self-government bodies, which are determined by the peculiarities of the given territorial community: the quantitative and qualitative composition of the council, the system of 
its standing commissions; quantitative and qualitative composition of the executive committee, departments, departments, other executive bodies of the council; peculiarities of the status of mayor, mayor, mayor, if any.

The fifth section of «Self-Organizing Bodies» defines the system and nature (committees, councils, etc.) of these bodies, the nature of those powers delegated by this body, the list of communal property transferred to the management of these bodies, as well as the amount of funds that are sent to them from the local budget.

In the sixth section «Forms of direct implementation of local selfgovernment by the territorial community and its members» on the basis of the current legislation defines a system of such forms, due to the peculiarities of this territorial community (local referendums, consultative polls, general meetings of citizens at their place of residence, local initiatives, public hearings, community other nonprohibited forms). Regarding the peculiarities of holding local referenda, advisory polls, public hearings, the charter could specify the list of issues that should be subject to the above mentioned forms.

In the last section, Final and Final Provisions, other issues not covered by the previous sections could be envisaged: the symbolism of this territorial community; membership of the relevant council in associations or other voluntary local self-government associations, indicating the amount of annual membership contributions to these associations; the nature of the powers delegated respectively by the village, settlement, city councils to the district, regional council and under what conditions it was done; other issues ${ }^{17}$.

The acts of bodies and officials of local self-government on the grounds of their inconsistency with the Constitution or the laws of Ukraine are declared illegal in court.

The acts of bodies and officials of local self-government are brought to the attention of the population. At the request of citizens, they may be issued a copy of the relevant acts of local self-government bodies and officials.

\section{CONCLUSIONS}

Therefore, local government is a separate form of exercise of public authority. The signs of local self-government in Ukraine are:

\footnotetext{
${ }^{17}$ Ryndyuk V.I. (2009) Normotvorcha diyal'nist' [Rule-making activity] Kyiv: KNEU. P. 107. (in Ukrainian).
} 
local self-government is structured in the system of public authority in the form of public-self-government in the process of the state's awareness of the presence of other, non-state interests - interests of local character, which are not identical to the state, but not contrary to them;

local self-government is characterized by a high level of democracy and its subject is a territorial community consisting of residents who are permanently resident within a certain territory;

The main purpose of structuring local self-government in the public authority system is to address local issues most effectively.

Many social relations, in view of their content, local conditions and peculiarities, require the publication of normative-legal acts of local selfgovernment in order to specify the norms of legislation.

Implementation of normative competence of local self-government bodies is carried out by making normative decisions. Regulatory decisions can be made both directly by the territorial community through a local referendum and through representative bodies of local selfgovernment (village, settlement, city, district and regional councils).

The system of representative bodies of local self-government consists of: village, settlement, city councils; district, regional councils. Councils, their executive committees and standing committees, within the limits of their powers, adopt regulations in the form of decisions. Rulemaking competence of village, city mayors, heads of rayon in the city, rayon, regional council is realized in the form of orders.

\section{SUMMARY}

The article deals with the legal status of local self-government bodies as law-makers. It is noted that local self-government is a separate form of exercise of public authority. The features of local self-government in Ukraine are presented, in particular: local self-government is structured in the system of public authority in the form of public self-government; is characterized by a high level of democracy, and its subject is a territorial community consisting of residents who are permanently resident within a certain territory; The main goal of local government is to address local issues most effectively.

The author concludes that many public relations, in view of their content, local conditions and features, require the publication of normative legal acts of local self-government in order to specify the norms of legislation.

It is emphasized that the legislative-making competence of local selfgovernment bodies is realized through the adoption of regulatory 
decisions. Regulatory decisions can be made both directly by the territorial community through a local referendum and through representative bodies of local self-government (village, settlement, city, district and regional councils).

Representative bodies of local self-government constitute a system of two levels: village, town, city councils; district, regional councils. Councils, their executive committees and standing committees, within the limits of their powers, adopt regulations in the form of decisions. Rulemaking competence of village, city mayors, heads of rayon in the city, rayon, regional council is realized in the form of orders.

\section{REFERENCES}

1. Asotsiatsiya mist Ukrayiny [Association of Ukrainian Cities]. URL:https://www.auc.org.ua/proposal.

2. Pro Derzhavnyy fond spryyannya mistsevomu samovryaduvannyu $v$ Ukrayini [About the State Fund for Promotion of Local Self-Government in Ukraine]: Presidential Decree of June 24, 2010, № 723/2010. URL:https://zakon.rada.gov.ua/laws/show/723/2010

3. Konstytutsiya Ukrayiny [Constitution of Ukraine]: Adopted at the fifth session of the Verkhovna Rada of Ukraine on June 28, 1996. URL: $\quad$ https://zakon.rada.gov.ua/laws/show/254\%D0\%BA/96-\%D0\% B2\%D1\%80

4. Yevropeys'ka khartiya mistsevoho samovryaduvannya [European Charter of Local Self-Government]: 15 October 1985. URL:https://zakon.rada.gov.ua/laws/show/994_036

5. Pro mistseve samovryaduvannya $v$ Ukrayini [On Local Government in Ukraine]: Law of Ukraine of May 21, 1997, № 280/97BP. - URL: https://zakon.rada.gov.ua/laws/show/280/97-вр

6. Barksiy V.R. (2006) Normotvorchist' predstavnyts'kykh orhaniv mistsevoho samovryaduvannya v Ukrayini [Rulemaking of representative bodies of local self-government in Ukraine]. - Odessa. - $221 \mathrm{p}$.

7. Maslovskaya T.S. (1998) Normotvorchestvo organov mestnogo samoupravleniya Rossiyskoy Federatsii [Rulemaking of local authorities of the Russian Federation]. - Omsk. - 23 p. (in Russian).

8. Shugrina E.S. (2000) Munitsipal'noye pravo [Municipal Law]. Moscow: Case. -496 s. (in Russian).

9. Onischenko N. (2002) Yurydychnyy protses yak forma pravovoyi diyal'nosti [Legal process as a form of legal activity] Law of Ukraine. № 7. - Pp. 7-13. (in Ukrainian). 
10. Bilenchuk P.D, Kravchenko V.V., Podmogilny M.V. (2000) Mistseve samovryaduvannya v Ukrayini (munitsipal'ne pravo) [Local Self-Government in Ukraine (Municipal Law)] Kyiv: Attica. - 304 p. (in Ukrainian).

11. Pogorilko V.F., Fritsky O.F. (2001) Munitsypal'ne pravo Ukrayiny [Municipal Law of Ukraine] Kyiv: YurinkomInter. - 352 p. (in Ukrainian).

12. Rusnak B.A. (2011) Mistseve samovryaduvannya v Ukrayini: teoriya $i$ praktyka [Local self-government in Ukraine: theory and practice]. - Odessa. - 536 p. P. 127. (in Ukrainian).

13. Ryndyuk V.I. (2009) Normotvorcha diyal'nist' [Rule-making activity] Kyiv: KNEU. - P. 107. (in Ukrainian).

\section{Information about the author:} Roman Liashuk,

Doctor of Juridical Sciences, Head of the Department of Theory and History of State and Law and private law disciplines, National Academy of the State Border Guard Service of Ukraine named after Bohdan Khmelnytskyi

Shevchenko street 46, apartment 59

Khmelnytskyi, Ukraine, 29000

ORCID ID: orcid.org/0000-0003-0137-0989 